\section{(2)}

\section{Psychology \& Neuroscience}

ISSN: 1984-3054

landeira@puc-rio.br

Pontifícia Universidade Católica do Rio de Janeiro

Brasil

Solovieva, Yulia; Quintanar Rojas, Luis

Syndromic analysis of ADHD at preschool age according to A.R. Luria concept

Psychology \& Neuroscience, vol. 7, núm. 4, 2014, pp. 443-452

Pontifícia Universidade Católica do Rio de Janeiro

Rio de Janeiro, Brasil

Available in: http://www.redalyc.org/articulo.oa?id=207032913003

- How to cite

Complete issue

More information about this article

Journal's homepage in redalyc.org

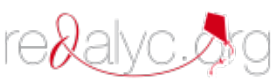

Scientific Information System Network of Scientific Journals from Latin America, the Caribbean, Spain and Portugal Non-profit academic project, developed under the open access initiative 


\title{
Syndromic analysis of ADHD at preschool age according to A.R. Luria concept
}

\author{
Yulia Solovieva and Luis Quintanar Rojas \\ Benemérita Universidad Autónoma de Puebla, Puebla, PUE, Mexico
}

\begin{abstract}
Different authors have studied attention-deficit/hyperactivity disorder (ADHD) in preschool children from different perspectives. Neuropsychological assessment can detect many kinds of cognitive difficulties, but the common syndromic picture has not yet been established. The idea of the existence of a specific neuropsychological syndrome based on A.R. Luria's concept differs from syndromes that are established in the Diagnostic and Statistical Manual of Mental Disorders, $4^{\text {th }}$ edition. The goal of the present study was to show qualitative parameters and features of cognitive activity in Mexican preschool children who receive a diagnosis of ADHD at preschool age. The proposal of such an analysis is for the whole syndrome. Neuropsychological assessment was applied to a group of Mexican preschool children with ADHD using the qualitative approach. Specific difficulties were observed not only with regard to frontal cortical function but also with spatial processing and the tone of general brain activation. The qualitative analysis of the data obtained by neuropsychologically assessing ADHD at preschool age allowed us to establish a specific complex of difficulties including functional weakness of the frontal and posterior associative cortical zones and general brain activation. New approaches to both assessment and remediation are urgently needed for preschool children in Latin America. Keywords: attention-deficit/hyperactivity disorder, child neuropsychology, child assessment, syndromic analysis, neuropsychological syndrome.
\end{abstract}

Received 10 April 2014; received in revised form 10 September; accepted 27 October. Available online 16 December 2014.

\section{Introduction}

The end of preschool age and beginning of school learning is an important period for cognitive and personal development. According to psychological, neuropsychological, and physiological research, the preschool age is associated with significant changes and transformations (Vigotsky, 1996; Elkonin, 1980; Semenova, Machinskaya, Akhutina, \& Krupskaya, 2001; Farber \& Njiokiktjien, 1993). Different developmental disorders can be detected at preschool age, among which attention-deficit/hyperactivity disorder (ADHD) is one of the most frequent.

Normally, different causes may be considered responsible for ADHD, such as genetic conditions that predominate in specific populations (Pineda \& Rosselli, 1997) or the existence of pathophysiological substrates (Heilman, Voeller, \& Nadeau, 1991; Paiva, 2003; Willis \& Weiler, 2005). From a neuropsychological point of view, the most important cause would involve the central nervous system. Such participation at the functional level may concern pathophysiological and organic problems and the possible lack of maturation.

Yulia Solovieva and Luis Quintanar Rojas, Master in Neuropsychology, Faculty of Psychology, Autonomous University of Puebla, Puebla, PUE., Mexico. Correspondence regarding this article should be directed to: Yulia Solovieva. E-mail: yulia.solovieva@correo.buap.mx
The lack of maturation is not among the most frequent topics addressed in modern neuropsychology or studies dedicated to ADHD in childhood.

Different authors have attempted to study ADHD in preschool children with the objective of detecting the mechanisms of the disorder and levels of disturbance, including possible effects at different levels of the central nervous system. The frontal lobes and diverse alterations in attentional processes are commonly described (Benson, 1991; Case, 1992; Barkley, 2001, Gustafsson, Thernlund, Ryding, Rosén, \& Cederblad, 2000; Capilla-González et al., 2005). Disturbances in executive function are considered the central and even unique problem associated with the disorder (Barkley, 2001; Zavadenko, 2000; Castellanos \& Acosta, 2004).

Nevertheless, in other studies, other processes and not only attention itself are mentioned as severely impaired and significant in this syndrome. For example, severe problems with spatial orientation and other aspects of spatial functions in Mexican preschool children were reported in our previous studies (Quintanar, Solovieva, \& Bonilla, 2006). Significant difficulties with global and analytic spatial perception were detected in this study. According to such data, both attention itself and dysregulated frontal cortical lobes associated with executive function are the main areas of dysfunction in ADHD at preschool age. The use of different neuropsychological methods implies different 
levels of analysis that need to be related to each other. For example, what is the relationship between spatial perception and executive function? It is not clear from the cognitive perspective whether attention and executive function represent unique processes, are elements within the same system, or are independent phenomena. Shall we believe that spatial orientation is part of executive function, or vice versa? Should attention be considered a part of executive function?

Historical-cultural neuropsychology, founded by Luria (1973a), offers an integrative functional analysis of the brain mechanisms that determine the clinical features of ADHD. Such information may be obtained through the qualitative analysis of errors and particular features that are observed during the implementation of brief neuropsychological assessment (Solovieva \& Quintanar, 2009).

Different interpretations of the term "syndrome" exist. According to the classic interpretation, a syndrome is a complex of symptoms that can be found in the Diagnostic and Statistical Manual of Mental Disorders, $4^{\text {th }}$ edition, text revision (DSM-IV-TR; American Psychiatric Association, 2000). According to Luria's methodology, a neuropsychological syndrome is one of the essential concepts of neuropsychological and functional organization of the brain and functional systems. However, this concept is usually not mentioned in the majority of his publications (Luria, 1970a). Tsvetkova (2004, p. 73) wrote that a neuropsychological syndrome represents "selective deficits of a group of psychological functions, whose structure includes the same damaged factor with the conservation of other functions, which do not include this factor." The concept of a "syndrome" was proposed by Luria (1970b) specifically for the clinic analysis of cases of adults with acquired brain damage. The schools and followers of his concept have used the same concept for different clinical pictures in both adults and children (Simernitskaya, 1985; Xomskaya, 1987; Santana, 1999; Tsvetkova, 2001, 2004; Solovieva, Lázaro, \& Quintanar, 2008).

Clinical application of the concept of a neuropsychological syndrome opens the possibility of considering common reasons (or "factors," according to Luria) of all difficulties observed in each clinical case. Such cases could be possibly generalized if they are commonly observed in the same age with the same typical qualitative features. To precisely define these qualitative features, it may be useful to use Luria's term "factor." Neuropsychological factors may be understood as psychophysiological mechanisms that are responsible of the majority of all of the observed symptoms, developmental difficulties, and learning disabilities (Xomskaya, 2002). Typical problems observed in intellectual tasks according to age and daily behavior may also be explained with the help of detecting neuropsychological factors. Neuropsychological factors can always be related to general or specific levels of the central nervous system.
We can recall the concept of three functional blocks of the brain proposed by Luria, which has been broadly accepted in modern neuropsychology (Xomskaya \& Akhutina, 1998). Neuropsychological factors may thus be related to subcortical systems of general regulation (i.e., the first functional block), cortical posterior zones (i.e., the second functional block), and cortical frontal zones (i.e., the third functional block).

According to Luria's neuropsychological concepts (Luria, 1973b; Xomskaya, 2002; Tsvetkova, 2004), such factors as common reasons for difficulties that cannot be identified only on the basis of the methodology of quantification or assessment of isolated cognitive functions, such as language, memory, or attention. The difficulty finding such neuropsychological factors or common reasons is related to the fact that isolated cognitive functions are usually assessed and even measured during neuropsychological assessment (Weschler, 1987). The qualitative procedure of assessment must provide specific information for the specialist to identify the predominant reasons for difficulties from the point of view of the central nervous system. The determination of neuropsychological factors provides a description of the difficulties and permits the establishment of relationships with the functional and maturational aspects of the central nervous system. Without the establishment of such relationships, the specialist will always remain at the position of simply associating one difficulty with another. For example, we can associate attention deficits with aggressive behavior (Halperin et al., 1999).

In child neuropsychology, the relationship with the central nervous system implies the establishment of the level of maturation more than the localization of "lesions" of subcortical or cortical functional structures. We must separate cases that lack physiological maturation at different subcortical levels from cases that have cortical dysfunction, which is not common in modern neuropsychology. The majority of previous studies used the following logic. Attention deficits impact executive function, and executive function impacts frontal orbital lobes and their "minimum lesion" (Wikler, Dixon, $\&$ Parker, 1970). Another way of thinking of this is also possible. Such a position is mainly reflected by historical and cultural concepts of human development, clinical psychology, and neuropsychology, which share this concept (Xomskaya \& Akhutina, 1998). Specific features of clinical assessment in infancy involve evaluation of the effects of brain damage or immaturity, which can be expressed in very generalized and diffusive ways compared with the same effects in adults. The whole personality and activity of the child suffers, and no progress in psychological development may be observed (Slepovich \& Poliakova, 2012; Zvereva, Kazmina, \& Karimulina, 2008).

The idea of the existence of a specific neuropsychological syndrome differs from syndromes that are established in the DSM-IV-TR (American Psychiatric Association, 2000). The syndrome can never 
be reduced to only one "cognitive function," such as "attention deficit disorder," dyscalculia, dyslexia, and dysgraphia. The syndrome always includes difficulties with diverse kinds of actions of the child. Instead of psychometric assessment or the assessment of isolated cognitive functions, a qualitative scheme for syndromic assessment may be proposed. Based on such a scheme, we may include the level of psychophysiological mechanisms as neuropsychological factors that must be evaluated functionally during assessment.

As a qualitative conclusion after completing a syndromic analysis, we obtain judgments at four levels: (1) the involvement of neuroanatomical structures or the level of maturation of the central nervous system, (2) predominant neuropsychological factors, (3) actions that correspond to psychological age and personality, and (4) speech production or neurolinguistic level of development. Each level should be characterized according to positive and negative aspects of development and the learning of each child through neuropsychological assessment. Such levels can be studied in an interdisciplinary manner, including specialists in neuroimaging or electrophysiology (Solovieva et al., 2013). Table 1 presents specific information that should be directly obtained by neuropsychologists or in collaboration with other specialists at three levels: (1) central nervous system, (2) neuropsychology, and (3) psychology.

Each level of syndromic neuropsychological analysis involves specific methods and instruments for assessment and qualitative analysis. Neuropsychological assessment seeks to establish weak and strong functional brain mechanisms associated with children's activity (Akhutina \& Pilayeva, 2008). This assessment uses specific tasks to evaluate programming and control, phonemic and kinesthetic integration, motor sequence organization, spatial functions, and retention in the

Table 1. Levels of syndromic analysis

\begin{tabular}{ll}
\hline Level & Syndromic analysis \\
\hline $\begin{array}{l}\text { Central nervous } \\
\text { system }\end{array}$ & $\begin{array}{l}\text { 1. Level of maturation or lack of maturation } \\
\text { of cortical/subcortical systems. } \\
\text { 2. Organic lesions during embryonic period, } \\
\text { pre- or perinatal, or lesions during first } \\
\text { year of life. }\end{array}$ \\
& $\begin{array}{l}\text { 3. Lesions acquired during long periods of } \\
\text { infancy (after first year). }\end{array}$ \\
Neuropsychology & $\begin{array}{l}\text { Sufficient or low functional state of different } \\
\text { brain cortical and subcortical mechanisms, } \\
\text { which are the basis of functional systems }\end{array}$ \\
& $\begin{array}{l}\text { according to specific cultural activity of the } \\
\text { child within a precise developmental period } \\
\text { (psychological age). }\end{array}$ \\
Psychology & $\begin{array}{l}\text { Psychological age: } \\
\text { 1. Social development. }\end{array}$ \\
2. Dominant type of activity of the age. \\
3. New psychological formations of the age. \\
4. Communicative activity and social \\
contacts.
\end{tabular}

visual and verbal modalities (Mikadze, 2012; Akhutina \& Pilayeva, 2012; Quintanar \& Solovieva, 2008; Solovieva, Lazaro \& Quintanar, 2008).

Physiological methods, including visual analysis of electroencephalograms (EEGs), can establish the precise participation of different systems of brain regulatory systems (Machinskaya, Lukashevich, \& Fishman, 1997). The results of neuropsychological assessment and analyses of EEG data normally appear separately in different neuropsychological and physiological studies. Our own experience and the experience of our colleagues show that such separation is not obligatory. In some studies, a correlation between neuropsychological assessment results and the data obtained by applying a visual qualitative analysis of EEGs has been reported (Machinskaya et al., 1997). In our own previous study, comparisons and correlations of clinical data on the manifestations of ADHD at preschool age were made using different methods that combined neuropsychological and electrophysiological assessment and posterior qualitative analysis. For example, no cortical difficulties were found in children with ADHD. The level of maturation and functioning of cortical zones according to parameters of alpha rhythm did not show any differences with a control group of the same age and same social cultural conditions (Solovieva, Machinskaya, Bonilla, \& Quintanar, 2007; Solovieva et al., 2013). In contrast, the level of maturation and functioning of subcortical systems of regulation was not sufficient for their age. Differences were found at the level of both the reticular formation (brainstem) and frontal thalamus. No differences were found between Mexican and Russian preschool children with the same kinds of difficulties, and no differences were found between girls and boys (Solovieva et al., 2013). All of the problems that were observed in preschool children with ADHD did not appear to be attributable to some kind of brain damage or "frontal minimal lesion" or other types of lack of cortical maturation. Instead, the differences appeared to be attributable to an insufficient level of maturation and functioning of subcortical regulatory systems (Machinskaya \& Krupskaya, 2001).

Such data have provided a new perspective of cases of ADHD as pure cases of attentional difficulties based only on the presence or absence of symptoms that are detected by interview and assessed only according to the DSM-IV-TR. In our opinion, only the presence or absence of these symptoms has no specific correlation with the functional stage of the central nervous system or maturational features of this age. According to the neuropsychological approach proposed by A.R. Luria, a simple description of symptoms cannot be considered sufficiently profound clinical analysis.

\section{Objectives}

The objective of the present study was to show qualitative parameters and features of cognitive activity in Mexican preschool children who received a diagnosis 
of ADHD at preschool age. After identifying such qualitative parameters, we can characterize the clinical picture and obtain a generalized neuropsychological syndrome.

\section{Methods}

\section{Sample}

The children included in the study were 16 Mexican preschool children with a diagnosis of ADHD made by a local child psychologist, child neurologist, or child psychiatrist. The diagnosis was based on the DSMIV-TR (American Psychiatric Association, 2000). The children were selected from regular kindergarten classes and from the Centers of Attention of Preschool Children with Developmental Disorders in the city of Puebla, Mexico. All of the children belonged to an urban zone in the city of Puebla and attended official preschool institutions. The age of the children was 5-6 years with the average age of 5.1. All of the children presented sufficient ADHD characteristics for more than 6 months. The children presented no other kinds of problems or illnesses with their psychological development or health.

\section{Neuropsychological assessment}

The neuropsychological assessment was performed according to the theory of Luria (1973a) and its later development in modern child neuropsychology (Akhutina, 2002; Akhutina \& Pilayeva, 2003; Mikadze, 2012). Special instruments were developed for the Spanish-speaking child population age 5-12 years (Solovieva \& Quintanar, 2009; Quintanar \& Solovieva, 2010). The Brief Neuropsychological Assessment for Children includes special tasks to assess brain mechanisms related to the following three functional blocks according to Luria's proposal: functional block I (related to general brain activation and subcortical structures), functional block II (related to processing and conservation of information of various modalities and posterior cortical zones), and functional block III (related to programming and control and anterior cortical zones [e.g., frontal lobes]).

All of the tasks were elaborated and created by considering the cultural and linguistic features of Mexican children. The tasks were previously tested and applied to groups of normal Mexican preschool children from urban and rural zones (Quintanar \& Solovieva, 2003; Quintanar, Solovieva, \& Lázaro, 2008).

The objective of the Brief Neuropsychological Assessment for Children is to determine positive and negative functional states during action execution with regard to the following neuropsychological mechanisms:

1) Kinesthetic analysis and synthesis-functional block II.

2) Phonemic analysis and synthesis-functional block II.
3) Motor sequence organization of actions and movements - functional blocks II and III.

4) Spatial analysis and synthesis - functional block II.

5) Visual-verbal retention-functional block II.

6) Audio-verbal retention-functional block II.

7) Programming and control—functional block III.

8) General brain activation of cortical tone-functional block I.

Special tasks were created to observe neuropsychological mechanisms during the child's execution of actions (Table 2).

Table 2. Structure of tasks of the Brief Neuropsychological Assessment for Children (Solovieva and Quintanar, 2009).

\begin{tabular}{|c|c|}
\hline $\begin{array}{l}\text { Neuropsychological } \\
\text { aspects }\end{array}$ & Tasks \\
\hline $\begin{array}{l}\text { Kinesthetic analysis } \\
\text { and synthesis }\end{array}$ & $\begin{array}{l}\text { Haptic recognition of common objects. } \\
\text { Repetition of syllables with close } \\
\text { articulations. } \\
\text { Poses of fingers. } \\
\text { Reproduction of poses of fingers with } \\
\text { closed eyes. } \\
\text { Production of fine articulation positions. }\end{array}$ \\
\hline $\begin{array}{l}\text { Phonemic analysis } \\
\text { and synthesis }\end{array}$ & $\begin{array}{l}\text { Repetition of words with opposing } \\
\text { phonemes (significant for Spanish } \\
\text { language). } \\
\text { Repetition of syllables with opposing } \\
\text { phonemes. } \\
\text { Identification of opposing sounds in } \\
\text { series of sounds. }\end{array}$ \\
\hline $\begin{array}{l}\text { Motor organization } \\
\text { of actions and } \\
\text { movements }\end{array}$ & $\begin{array}{l}\text { Dynamic coordination of hands. } \\
\text { Dynamic coordination of fingers. } \\
\text { Copy and continuation of a graphic } \\
\text { sequence. }\end{array}$ \\
\hline $\begin{array}{l}\text { Spatial analyses and } \\
\text { synthesis }\end{array}$ & $\begin{array}{l}\text { Copy of a house. } \\
\text { Free drawing of girl and boy. } \\
\text { Comprehension of complex grammar } \\
\text { structures. }\end{array}$ \\
\hline Visual-verbal retention & $\begin{array}{l}\text { Copy and evocation of five letters. } \\
\text { Copy and evocation of five complex } \\
\text { figures. }\end{array}$ \\
\hline Audio-verbal retention & $\begin{array}{l}\text { Direct repetition of two series of three } \\
\text { words. } \\
\text { Involuntary evocation of two series of } \\
\text { three words. } \\
\text { Voluntary evocation of two series of } \\
\text { three words. } \\
\text { Retarded evocation of two series of } \\
\text { three words. }\end{array}$ \\
\hline $\begin{array}{l}\text { Programming and } \\
\text { control }\end{array}$ & $\begin{array}{l}\text { Verbal conflicting instructions presented } \\
\text { as a game. } \\
\text { Free game. } \\
\text { Directed game. } \\
\text { Marching by instruction. } \\
\text { Marching by palming. } \\
\text { Shultz table. } \\
\text { Following oral verbal instructions. } \\
\text { Identification of smiling faces in a series } \\
\text { of smiling, indifferent, and sad faces. }\end{array}$ \\
\hline $\begin{array}{l}\text { General brain } \\
\text { activation }\end{array}$ & $\begin{array}{l}\text { The whole procedure of execution of all } \\
\text { tasks, way of communication, social } \\
\text { contacts. }\end{array}$ \\
\hline
\end{tabular}




\section{Procedure}

All of the children underwent neuropsychological assessment, which was applied in two or three individual sessions that lasted 40-60 min. A qualitative analysis of the results of the neuropsychological assessment was performed for all of the children to identify qualitative clinical syndromes.

Examples of the execution of the tasks in the assessment are presented in Figures 1-6.

The qualitative analysis included the types of mistakes and difficulties of the children during fulfillment of the tasks, observations of the entire procedure of test application, the behavior and communication of children with adults, and a clinical history to determine a functional positive or negative state of the aforementioned brain mechanisms. Knowledge of both neuropsychological theory and methodology (Luria, 1973a; 1974, 1977) and typical psychological features of preschool age (Oboukhova, 2006; Elkonin, 1995;

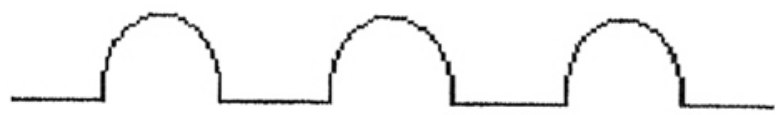

Figure 1. Task of copy and continuation of graphic sequence model.

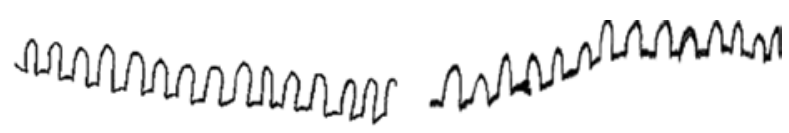

Figure 2. Examples of execution by control group of the same age.

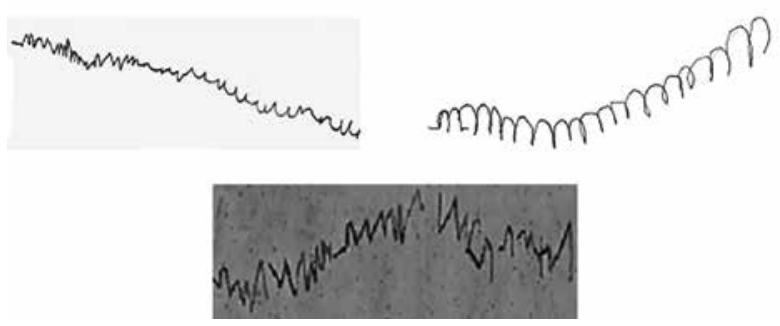

Figure 3. Examples of execution of the task in the group with ADHD.

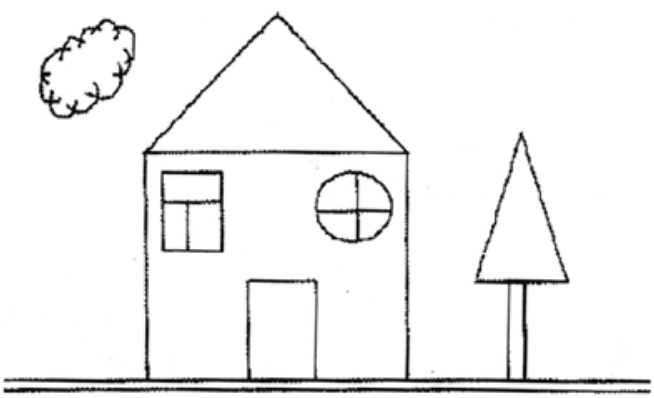

Figure 4. Model for copy of the house.
Solovieva \& Quintanar, 2012), together with clinical experience and the ability to establish close emotional contact with the child, are necessary requirements for neuropsychologists. Such professional preparation helps qualify different errors and difficulties during assessment and relate them to the functional state of brain mechanisms. Such a procedure and consideration of strong and weak aspects of the child's activity, together with the establishment of qualitative interpretations and relations with central nervous system function, are the ways in which a syndromic analysis can be realized according to A.R. Luria's neuropsychological theory.

\section{Results}

The results of neuropsychological assessment demonstrated severe functional deficits in the functions that are traditionally related to "processes of attention" or functional block II and mechanisms related to all three functional blocks established by Luria (1974), including
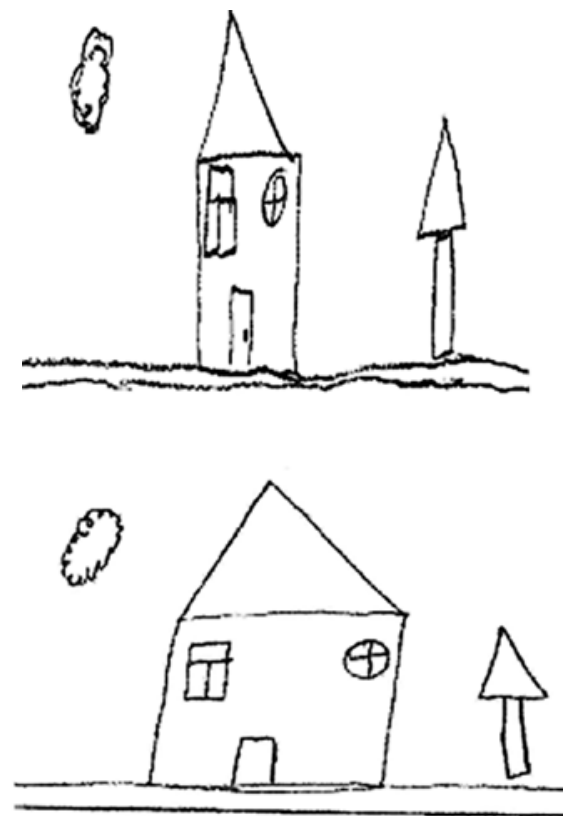

Figure 5. Examples of execution by control group of the same age. $\approx$
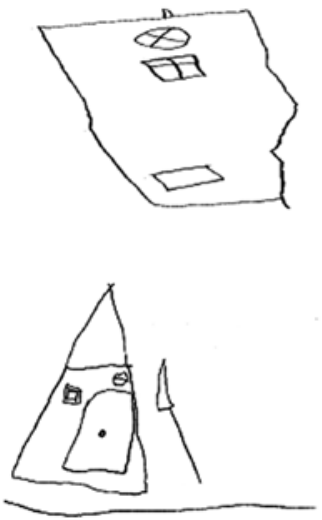
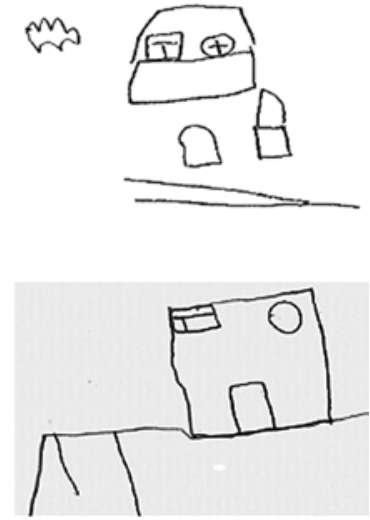

Figure 6. Examples of execution of the task in the group with ADHD. 
programming and control, motor organization of movements and actions, spatial analysis and synthesis, and nonspecific brain activation. These difficulties can be related to the model of three functional blocks proposed by A.R. Luria. This relationship is very useful for unifying and concentrating the types of difficulties of the children with ADHD.

Table 3 presents the results of the qualitative analysis obtained through neuropsychological assessment and generalized for all of the tested children.

The general results of the neuropsychological assessment with the help of specific tasks permits one to speak about significant difficulties in three aspects of brain function:

1) Programming and control of child's activityfunctional block III.

2) Spatial analysis and synthesis - functional block II.

3) Working functional state of child's activityfunctional block I.

Table 4 shows some examples of typical performance by preschool children with ADHD. Difficulties in all three functional blocks of the brain can be found in these examples.

\section{Discussion}

The results of executing the neuropsychological tasks by the children with ADHD and children without any disorder were compared. The results revealed significant differences in favor of children without ADHD, whereas children with ADHD showed a specific neuropsychological profile that was characterized by a severe functional deficit in programming and control mechanisms, motor sequence organization, spatial analysis and synthesis, and nonspecific brain activation. The clinical picture of ADHD at preschool age, therefore, is a complex neuropsychological syndrome, with the involvement of different mechanisms at different levels. Various psychological processes and brain mechanisms should be taken into account to guarantee effective methods and strategies for correction. The traditional term "attention deficit disorder" may no longer be suitable as a theoretical or clinical reference. This term should be considered only as a "day-to-day" symptom or characteristic of the child's personality and not as a term to describe the actual clinical picture or make a diagnosis. We are not presently proposing any new name for this particular syndrome, but we would like to stress the necessity of considering the complex structure and participation of subcortical (and not cortical) levels in this syndrome. Our findings may stress some kind of relationship with the complex comprehension of brain systems related to attention, which include important subcortical components (Posner \& Petersen, 1990).

In the present study, diverse manifestations at different levels of subcortical immaturity were detected in preschool age. The main typical qualitative signs were the following:

1) Lack of execution stability or low tone of execution.

2) Constant variations in completing the tasks.

3) Lack of self-verbal regulation.

4) Constant necessity for external help.

5) Constant necessity for extra motivation.

6) Possible perseverations at the verbal and graphic levels.

7) Severe spatial difficulties at the verbal and visual levels.

Table 3. Concentration of difficulties according to three functional brain blocks

\begin{tabular}{|c|c|c|c|c|c|}
\hline \multirow[b]{2}{*}{$\begin{array}{l}\text { Brain functional } \\
\text { blocks and related } \\
\text { tasks }\end{array}$} & \multicolumn{2}{|c|}{$\begin{array}{c}\text { Block I } \\
\text { Systems of general brain tone }\end{array}$} & \multicolumn{2}{|c|}{$\begin{array}{l}\text { Block II } \\
\text { Spatial analysis and synthesis }\end{array}$} & \multirow{2}{*}{$\begin{array}{l}\text { Tasks and general } \\
\text { observation for } \\
\text { Block III (system } \\
\text { of programming, } \\
\text { regulating, and } \\
\text { controlling general } \\
\text { activity) } \\
\text { Task: verbal } \\
\text { conflicting } \\
\text { instructions and } \\
\text { all tasks during the } \\
\text { assessment. }\end{array}$} \\
\hline & $\begin{array}{l}\text { Task: } \\
\text { Motor coordination } \\
\text { of hands and } \\
\text { fingers. }\end{array}$ & $\begin{array}{l}\text { Task: } \\
\text { Copy and } \\
\text { continuation of } \\
\text { graphic sequence. }\end{array}$ & $\begin{array}{l}\text { Task: } \\
\text { Free drawing of a } \\
\text { boy and girl. }\end{array}$ & $\begin{array}{l}\text { Task: } \\
\text { Copy of a model of } \\
\text { a house. }\end{array}$ & \\
\hline $\begin{array}{l}\text { Characteristics of } \\
\text { executions and types } \\
\text { of difficulties }\end{array}$ & $\begin{array}{l}\text { Slow execution or } \\
\text { impulsive execution, } \\
\text { fatigue, constant } \\
\text { distraction. }\end{array}$ & $\begin{array}{l}\text { Starts and leaves } \\
\text { the task, total } \\
\text { impossibility to } \\
\text { recognize the line, } \\
\text { lines and curves } \\
\text { without any sense, } \\
\text { macrography or } \\
\text { micrography in the } \\
\text { drawings. }\end{array}$ & $\begin{array}{l}\text { Absence of both } \\
\text { form and elements, } \\
\text { impossibility to } \\
\text { recognize the figures } \\
\text { and shapes in the } \\
\text { drawings, drawings } \\
\text { as a "head with } \\
\text { legs" which is a } \\
\text { characteristic of } \\
\text { younger age. }\end{array}$ & $\begin{array}{l}\text { Absence of both } \\
\text { form and elements, } \\
\text { impossibility to } \\
\text { recognize the } \\
\text { figures and shapes } \\
\text { in drawings, } \\
\text { "mirror" mistakes, } \\
\text { disintegration of } \\
\text { elements, inversions } \\
\text { of elements. }\end{array}$ & $\begin{array}{l}\text { Absence of } \\
\text { regulation by adult's } \\
\text { language or child's } \\
\text { own language, } \\
\text { constant motor } \\
\text { perseverations } \\
\text { in graphic tasks, } \\
\text { impossibility to } \\
\text { follow instructions, } \\
\text { losing the objective, } \\
\text { losing the program } \\
\text { of execution in all } \\
\text { motor tasks. }\end{array}$ \\
\hline
\end{tabular}


Table 4. Execution of the tasks during neuropsychological assessment

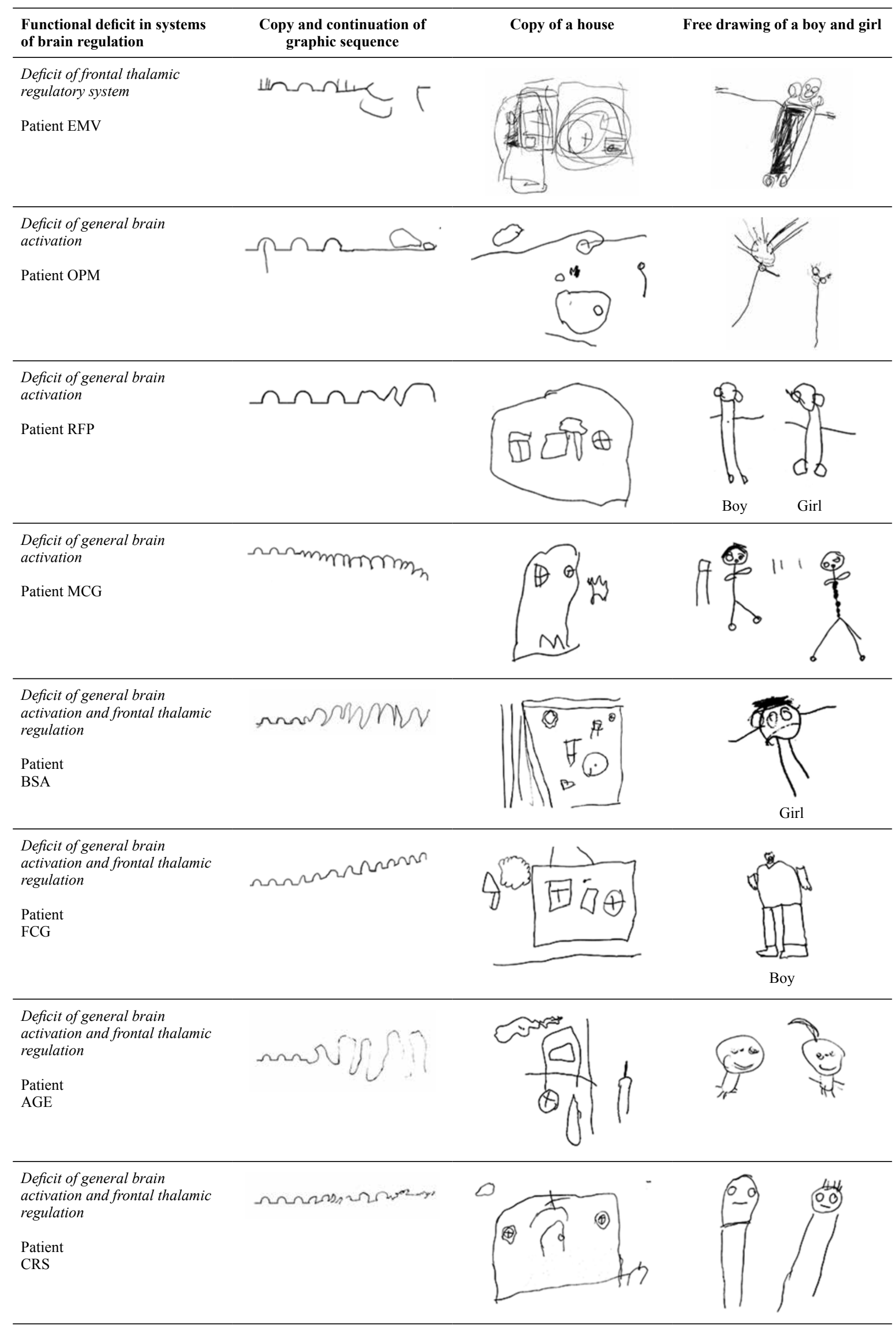


According to our results, particular characteristics of this clinical picture may exist during preschool age. Each qualitative feature could be related to one of three functional brain blocks according to A.R. Luria's neuropsychological concept (1973b). In this syndrome, diverse and heterogeneous difficulties occur. Such difficulties do not show the typical expression of focal cortical problems but rather the more global diffuse participation of subcortical levels of regulation. The most important neuropsychological mechanisms are the following: insufficient level of general brain tone/ activation and difficulties regulating and controlling expressive spatial difficulties (Solovieva et al., 2013).

Different manifestations of ADHD could be related to particular stages and unequal functional immaturity at different levels of brain regulatory systems according to specific ontogenetic periods (Bezrukikh, Machinkaya, \& Sugrobova, 1999; Machinskaya, 2006). According to this supposition, the syndrome of ADHD will have different manifestations at different ages (e.g., preschool, primary school, and adolescence; Machinskaya \& Semenova, 2004). At preschool ages, neuropsychological assessment can detect a variety of problems in children that cannot be adequately termed ADHD. We consider that the traditional denomination of the syndrome of ADHD does not reflect the real nature and mechanisms of children's difficulties. The danger of this situation is that the methods for overcoming ADHD are commonly useless or wrong. Such methods are frequently limited to medicating the children or conducting formal measures, which only supposes the training of executive functions through constant repetition or simplification of the tasks. Instead of development, these methods rely on adapting to difficulties, with the possibility of future personal defects including the absence of self-confidence and dependence on medication.

The aforementioned difficulties and symptoms can be generalized according to the proposed levels for considering a neuropsychological syndrome (Table 5). From the global syndromic perspective, we may pass from an empiric description of isolated functions or behavior, such as with the DSM-IV-TR, to the integration of qualitative information that includes central nervous system and brain cortical and subcortical levels and psychological activity according to the age and features of personality. According to such a global interpretation, we may even state that some features (e.g., impulsiveness and hyperactivity) that are normally considered "reasons" or "internal symptoms" are nothing more than compensation for a low level of general brain activation. Based on this, we may even explain a certain tendency toward aggressive behavior. In Table 5, we propose a qualitative syndrome of low maturation of subcortical regulatory systems called "cases with attention deficit disorder." We follow A.R. Luria's approach and his proposal of qualitatively considering both the negative and positive aspects of the syndrome at diverse levels: central nervous system, neuropsychology, and psychology. We may also suppose that additional levels may be considered in the future.

Our results also show the necessity of including specific methods to correct weak aspects of development and the level of maturation of subcortical regulatory systems. According to our data, neuropsychological correction should also recognize the necessity of including methods to correct not only regulation and control strategies but also spatial functions in populations of children with ADHD at the preschool age (Quintanar et al., 2006). Such features as impulsiveness and hyperactivity should be understood not as internal symptoms but rather self-involuntary compensation. Gradual involvement in social role games, the usage of external types of regulation and materialization, and constant verbal and nonverbal orientation (Quintanar, Hernández, Bonilla, Sánchez, \& Solovieva, 2001) are appropriate ways to form an optimal functional state of general brain activation.

Only complex programs of directed activity that are divided between an adult and a child according to Vigotsky's principal of joint activity can guarantee success in the psychological and cognitive development of children with ADHD (Solovieva, Quintanar, \& Bonilla, 2003; Quintanar, Lázaro, Bonilla, \& Solovieva, 2007). The programs should be based on the concept of games with rules as dominant psychological activity of

Table 5. Levels of syndromic analysis in ADHD

\begin{tabular}{|c|c|c|}
\hline Central nervous system & Neuropsychology & Psychology \\
\hline $\begin{array}{l}\text { 1. Lack of functional maturation of } \\
\text { subcortical regulatory systems: reticular } \\
\text { formation (brainstem) and frontal } \\
\text { thalamus } \\
\text { 2. Absence of organic brain damage } \\
\text { 3. Positive functional state of cortical zones. }\end{array}$ & $\begin{array}{l}\text { 1. Difficulties with regulation and control } \\
\text { 2. Difficulties with spatial functions } \\
\text { 3. Low level of general brain activation } \\
\text { 4. Positive functioning of phonemic } \\
\text { and phonemic analysis, kinesthetic } \\
\text { integration, and all primary cortical zones }\end{array}$ & $\begin{array}{l}\text { Psychological age: } \\
\text { 1. Lack of verbal complex communication } \\
\text { in families } \\
\text { 2. Impossibility of inclusion of complex role } \\
\text { games, only manipulative games with } \\
\text { initial stage of symbolic games } \\
\text { 3. Lack of voluntary development, absence } \\
\text { of drawing activity } \\
\text { 4. Common emotional conflicts and } \\
\text { difficulties communicating with mates } \\
\text { 5. Hyperactivity and impulsiveness as } \\
\text { compensation for low level of activation } \\
\text { may be noticed as predominant features } \\
\text { of personality }\end{array}$ \\
\hline
\end{tabular}


preschool age and of zone of proximate development accessible for preschool age according to Vigotsky (1991), which permits the gradual involvement of the child into different kinds of joint activity. Weak neuropsychological regulation and control mechanisms and spatial functions and a low level of general activation should also be considered and included as functional elements into actions proposed by an adult (Solovieva \& Quintanar, 2008). Such programs are currently created and applied in our day-to-day practice of neuropsychological correction in Mexico and other countries in Latin America. A new comprehension of the features of the personalities of children with regulation problems may be achieved as a result of qualitative neuropsychological research based on the approach created by A.R. Luria.

Our discussion and conclusions are limited to preschool age and a specific neuropsychological syndrome. Our future efforts will be directed toward analyzing such syndromes at other ages (e.g., primary school). A qualitative study of typical manifestations of neuropsychological syndromes at different levels should become one of the main interests of different specialists.

\section{Conclusions}

The qualitative analysis of the data obtained through neuropsychological assessment of ADHD at preschool age allowed us to establish a specific complex of difficulties: functional weakness of frontal and posterior associative cortical zones and general brain activation. Our results show the necessity of including specific methods of correction to form regulation and control strategies and spatial functions in a population of children with ADHD at preschool age. There are specific manifestations of functional difficulties with the formation of complex brain systems at different periods of ontogenetic development. The general results of neuropsychological assessment using specific tasks allows us to report significant difficulties in three aspects of brain function: programming and control of child's activity (functional block III), spatial analysis and synthesis (functional block II), and working functional state of child's activity (functional block I). New approaches for assessment and remediation are urgently required for preschool children in Latin America.

\section{References}

Akhutina, T. V. (2002). L. S. Vigotsky y A. R Luria: la formación de la neuropsicología. Revista Española de neuropsicología, 4(2-3), 108-129.

Akhutina, T. V., \& Pilayeva, N. M. (2003). El diagnóstico del desarrollo de las funciones visuo-verbales. Moscú: Academia.

Akhutina, T. V., \& Pilayeva, N. M. (2008). Diagnóstico neruopsicológico, evaluación de la escritura y la lectura en escolares menores. Moscú: Centro Creativo Sfera, V. Sekachev.

Akhutina, T. V. \& Pilayeva, N. M. (2012). Overcoming learning disabilities: a Vigotskian-Lurian neuropsychological approach. Cambridge: Cambridge University Press.

American Psychiatric Association (2000). Manual de diagnóstico estadístico de los trastornos mentales. Ciudad de México: Masson.

Barkley, R. A. (2001). The executive functions and self-regulation: an evolutionary neuropsychological perspective. Neuropsychological Review, 11, 1-29.
Benson, D. F. (1991). The role of frontal dysfunction in attention deficit hyperactivity disorder. Journal of Child Neurology, 6(Supp1), S9-S12.

Bezrukikh, M. M., Machinkaya, R. I., \& Sugrobova, G. A. (1999). Differentiated influence of the functional maturity of the cortex and brain regulatory structures on the characteristics of cognitive activity in 7-8 year old children. Human Physiology, 24(5), 510517.

Capilla-González, A., Pazo, P., Campo, P., Maestú, F., Fernández, A., Fernández-González, S., \& Ortiz, T. (2005). Nuevas aportaciones a la neurobiología del trastorno por déficit de atención con hiperactividad desde la magnetoencefalografía. Neurological Review, 40, 43-47.

Case, R. (1992). The role of the frontal lobes in the regulation of cognitive development. Brain and Cognition, 20, 51-73.

Castellanos, F. X. \& Acosta, M. T. (2004). Neuroanatomía del trastorno por déficit de atención con hiperactividad. Neurological Review, 38, 131-136.

Elkonin, D. B. (1980). Psicología de juego. Madrid: Visor.

Elkonin, D. B. (1995). Desarrollo psicológico en las edades infantiles. Moscú: Academia de Ciencias Pedagógicas y Sociales.

Farber, D., \& Njiokiktjien, C. (1993). Developing brain and cognition. Amsterdam: Suyi.

Gustafsson, P., Thernlund, G., Ryding, E., Rosén, I., \& Cederblad, M. (2000). Associations between cerebral blood-flow measured by single photon emission computed tomography (SPECT), electro-encephalogram (EEG), behaviour symptoms, cognition and neurological soft signs in children with attention-deficit hyperactivity disorder (ADHD). Acta Paediatrica, 89, 830-835.

Halperin, J. M, O’Brien, J. D., Newcorn, J. H., Healy, J. M., Pascualvaca, D. M., Wolf, L. E., \& Young, J. G. (1990). Validation of hyperactive, aggressive, and mixed hyperactive/aggressive childhood disorders: a research note. Journal of Child Psychology and Psychiatry, 31, 455-459.

Heilman, K. M., Voeller, K. K., \& Nadeau, S. E. (1991). A possible pathophysiologic substrate of attention deficit hyperactivity disorder. Journal of Child Neurology, 6(Suppl.), S76-S81.

Luria, A. R. (1970a). The functional organization of the human brain. Scientific American, 222, 66-72.

Luria, A. R. (1970b). Traumatic aphasia: its syndromes, psychology, and treatment. The Hague: Mouton.

Luria, A. R. (1973a). Bases de neuropsicología. Moscú: Universidad Estatal de Moscú.

Luria, A. R. (1973b). The origin and cerebral organization of man's conscious action. In S.G. Spair \& A.C. Nitzburg (Eds.), Children with learning problems: readings in a developmental-interaction (pp. 109-130). New York: Brunner/Mazel.

Luria, A. R. (1974). El cerebro en acción. Barcelona: Fontanella.

Luria, A. R. (1977). Las funciones corticales superiores del hombre. La Habana: Orbe.

Machinskaya, R. \& Semenova, O. (2004). Peculiarities of formation of the cognitive functions in junior school children with different maturity of regulatory brain systems. Journal of Evolutionary Biochemistry and Physiology, 40(5), 528-538.

Machinskaya, R. I. (2006). Functional maturation of the brain and formation of the neurophysiological mechanisms of selective voluntary attention in young school children. Human Physiology, 32(1), 20-29.

Machinskaya, R. I., \& Krupskaya, E. V. (2001). EEG analysis of the functional state of deep regulatory structures of the brain in hyperactive seven- to eight-year-old children. Human Physiology, 27(3), 368-370.

Machinskaya, R. I., Lukashevich, I. P., \& Fishman, M. N. (1997). Dynamics of brain electrical activity in 5 to 8 -year-old normal children and children with learning difficulties. Human Physiology, 23, 517-522.

Mikadze, Y. V. (2012). Neuropsicología de la edad infantil. Moscú: Piter.

Obukhova, L. F. (2006). Psicología del desarrollo por edades. Moscú: Educación Superior.

Paiva, H. (2003). Valoración neuropsicológica en el niño con TDA. In R. Santana, H. Paiva, \& I. Lustenberger (Eds.), Trastorno por déficit de atención con hiperactividad (pp. 89-116). Montevideo: Printer.

Pineda, D. \& Rosselli, M. (1997). Hiperactividad y trastornos atencionales. In M. Rosselli, A. Ardila, D. Pineda, \& F. Lopera (Eds.), Neuropsicología infantile: avances en investigación, teoría y práctica (pp. 253-278). Medellín: Prensa Educativa. 
Posner, M. I., \& Petersen, S. E. (1990). The attention system of the human brain. Annual Review of Neuroscience, 13, 25-42.

Quintanar, L., \& Solovieva, Y. (2003). Manual de evaluación neuropsicológica infantil. Puebla: Benemérita Universidad Autónoma de Puebla.

Quintanar, L., \& Solovieva, Y. (2008). Aproximación históricocultural: fundamentos teórico-metodológicos. In J. EslavaCobos, L. Mejía, L. Quintanar, \& Y. Solovieva (Eds.), Los trastornos de aprendizaje: perspectivas neuropsicologías: textos de neuropsicología Latinoamericana (pp. 145-182). Bogotá: Magisterio.

Quintanar, L., \& Solovieva, Y. (2010). Evaluación neuropsicológica del niño en la edad preescolar. Puebla: Universidad Autónoma de Puebla.

Quintanar, L., Hernández, A. L., Bonilla, M. R., Sánchez, A. R., \& Solovieva, Y. (2001). La función reguladora del lenguaje en niños con déficit de atención. Revista Latina de Pensamiento y Lenguaje, 9(2), 164-180.

Quintanar, L., Lázaro, E., Bonilla, R., \& Solovieva, Yu. (2007). Análisis neuropsicológico del déficit de atención: alternativas del tratamiento. In E. A. Escotto Córdova, M. Pérez Mendoza, \& N. A. Sánchez Cortés (Eds.), Lingüística, neuropsicología y Neurociencias ante los trastornes del desarrollo infantil (pp. 123140). Ciudad de México: UNAM.

Quintanar, L., Solovieva, Y., \& Bonilla, R. (2006). Analysis of visuospatial activity in preschool children with attention deficit disorder. Human Physiology, 32, 43-46.

Quintanar, L., Solovieva, Y., \& Lázaro, E. (2008). Evaluación neuropsicológica infantil breve para la población hispano-parlante. Acta Neurológica Colombiana, 24, 1-2: 31-44.

Santana, R. (1999). Aspectos neuropsicológicos del aprendizaje escolar. Santo Domingo: Innovaciones Psicoeducativas.

Semenova, O. V., Machinskaya, R. I., Akhutina, T. V., \& Krupskaya E. V. (2001). Brain mechanisms of voluntary regulation of activity during acquisition of the skill of writing in seven- to eight-year-old children. Human Physiology, 27, 405-412.

Simernitskaya, E. G. (1985). Cerebro humano y procesos psicológicos en la ontogenia. Moscú: Universidad Estatal de Moscú.

Slepovich, E. S. \& Poliakova, A. M. (2012). Psicología especial. Minsk: Escuela Superior.

Solovieva, Y., \& Quintanar, L. (2008). Educación neuropsicológica infantil. Ciudad de México: Trillas.

Solovieva, Y., \& Quintanar, L. (2009). Evaluación neuropsicológica infantil breve. Ciudad de México: Universidad Autónoma de Puebla.

Solovieva, Y., \& Quintanar, L. (2012). Actividad de juego en la edad preescolar. Ciudad de México: Trillas.
Solovieva, Y., Lázaro, E., \& Quintanar, L. (2008). Aproximación histórico-cultural: evaluación de los trastornos del aprendizaje. In J. Eslava-Cobos, L. Mejía, L. Quintanar, \& Y. Solovieva (Eds.), Los trastornos de aprendizaje: perspectivas neuropsicologias: textos de neuropsicología Latinoamericana (pp. 182-226). Bogotá: Magisterio.

Solovieva, Y., Machinkaya, R., Bonilla, R., \& Quintanar, L. (2007) Correlación neuropsicológica y electrofisiológica en niños con déficit de atención. Revista Española de Neuropsicología, 9(1), $1-15$.

Solovieva, Y., Machinskaya, R., Quintanar, L., Bonilla, R., \& Pelayo, H. (2013). Neuropsicología y electrofisiología del TDA en la edad preescolar. Puebla: Universidad Autónoma de Puebla.

Solovieva, Y., Quintanar, L., \& Bonilla, R. (2003). Propuesta de corrección neuropsicológica en niños con trastorno por déficit de atención. In R. Santana, H. Paiva, \& I. Lustenberger (Eds.), Trastorno por déficit de atención con hiperactividad (pp. 315-337). Montevideo: Printer.

Tsvetkova, L. S. (2001). Problemas actuales de la neuropsicología de la edad infantil. Moscú: Instituto Psicológico-Social de Moscú.

Tsvetkova, L. S. (2004). Rehabilitación de las funciones psíquicas superiores. Moscú: Universidad Estatal de Moscú.

Vigotsky, L. S. (1991). Problema de la enseñanza y desarrollo intellectual en la edad escolar. In Psicología pedagógica (pp. 374390). Moscú: Pedagogía.

Vigotsky, L. S. (1996). Obras escogidas. Tomo 4. Madrid: Visor.

Weschler, D. (1987). Weschler Memory Scale-Revised. New York: Psychological Corporation.

Wikler, A., Dixon, J. F., \& Parker, J. B., Jr. (1970). Brain function in problem children and controls: psychometric, neurological, and electroencephalographic comparisons. American Journal of Psychiatry, 127, 634-645.

Willis, W. G., \& Weiler, M. D. (2005). Neural substrates of childhood attention-deficit/hyperactivity disorder: electroencephalographic and magnetic resonance imaging evidence. Developmental Neuropsychology, 27, 135-182.

Xomskaya, E. D. (1987). Neuropsicología. Moscú: Universidad Estatal de Moscú.

Xomskaya, E. D. (2002). El problema de los factores. Revista Española de Neuropsicología, 4(2-3), 151-167.

Xomskaya, E. D., \& Akhutina, T. V. (1998). Primera conferencia internacional dedicada a la memoria de A. R. Luria. Moscú: Universidad Estatal de Moscú.

Zavadenko, N. (2000). Cómo entender al niño: niños con hiperactividad $y$ déficit de atención? Moscú: Pedagogía y Medicina.

Zvereva, N. V., Kazmina, O. Y., \& Karimulina, E. G. (2008). Patopsicología en la infancia y adolescencia. Moscú: Academia. 